\title{
Two Cases of Idiopathic Progressive Sensorineural Hearing Loss with Positional Nystagmus in Postpartum Period: Possible Spontaneous Perilymph Fistula?
}

\author{
Minhae Park ${ }^{D}$, Hee Jung Kim, and Won-Ho Chung ${ }^{(D)}$ \\ Department of Otorhinolaryngology-Head and Neck Surgery, Sungkyunkwan University School of Medicine, Samsung Medical Center, \\ Seoul, Korea
}

\section{수유모에서 발생한 체위성 안진을 동반한 감각신경성 난청 2예: 특발성 외림프누공의 가능성}

박민혜 · 김희정 · 정원호

성균관대학교 의과대학 삼성서울병원 이비인후과학교실

Received July 30,2020

Revised December 28, 2020

Accepted December 31, 2020

Address for correspondence

Won-Ho Chung, MD

Department of Otorhinolaryngology-

Head and Neck Surgery,

Samsung Medical Center,

Sungkyunkwan University

School of Medicine, 81 Irwon-ro,

Gangnam-gu, Seoul 06351, Korea

Tel $+82-2-3410-3577$

Fax $+82-2-3410-3879$

E-mail whchung12@gmail.com
Perilymph fistula (PLF) is defined as an abnormal communication between the middle ear cavity and perilymphatic space of the inner ear. Most cases of PLF are responsible for pressure change caused by internal trauma or external trauma. However, spontaneous PLF might occur without an obvious history of barotrauma. We report two cases of possible spontaneous PLF in the postpartum period: both cases involved progressive sensorineural hearing loss with positional dizziness. Although the leakage of perilymph was not found during exploration, both hearing loss and dizziness improved immediately after PLF repair. It is necessary to consider the possibility of PLF in patients who have sudden or progressive sensorineural hearing loss with positional nystagmus. Early surgical exploration is recommended even if the history of barotrauma is not clear.

Korean J Otorhinolaryngol-Head Neck Surg 2021;64(8):585-91

Key Words Hearing loss, sensorineural · Perilymph · Postpartum period.

\section{서 론}

외림프누공(perilymph fistula)은 내이의 외림프강(perilymphatic space)과 중이강(middle ear cavity) 사이에 비정상적 인 통로가 발생하여 외림프액이 중이강 내로 유출되는 질환 이다. 외림프누공의 원인으로는 외상, 내이 기형 등이 있으며, 특별한 원인 없이 자연 발생하는 경우도 있다.1) 외상성 외림프 누공은 두부 충격에 의한 외인성 외상(external trauma)이나, 코를 풀거나 무거운 물건을 들면서 발생하는 내부의 압력 변 화로 인한 내인성 외상(internal trauma)에 의해 발생할 수 있

This is an Open Access article distributed under the terms of the Creative Commons Attribution Non-Commercial License (https://creativecommons.org/licenses/by-nc/4.0) which permits unrestricted non-commercial use, distribution, and reproduction in any medium, provided the original work is properly cited.
다. ${ }^{2)}$ 이러한 외상으로 인해 내이에서 강한 압력 변화가 발생 하게 되면 정원창(round window)이나 난원창(oval window) 의 파열을 통하여 외림프액이 유출되면서 압력외상(barotrau$\mathrm{ma}$ )에 의한 외림프누공이 발생하게 된다. 특별한 원인없이 발 생하는 자발적 외림프누공은 Stroud와 Calcaterra ${ }^{3)}$ 에 의해서 처음 보고되었지만, 이에 대한 논란은 존재한다. Shea")는 자 발적으로 발생한 외림프누공은 있을 수 없다고 보고하였다. 자발적으로 발생했다기보다는 본인이 겪은 외상을 기억하지 못하는 경우가 많고, 해부학적으로 외상에 취약한 개인적인 차이가 있어서 일상 생활에서 흔히 일어나는 가벼운 외상에 의해서 외림프누공이 발생하는 경우가 있기 때문에 자발성보 다는 특발성으로 보는 견해들도 있다.5,6)

압력외상에 의한 외림프누공은 갑자기 발생하는 난청과 어 
지럼이 가장 전형적인 증상이다. ${ }^{7)}$ 일반적으로 증상의 발현은 외상 직후 나타나는 경우가 많으나 어떤 경우에는 외상 발생 후 수 시간에서 수일이 지난 후에 증상을 인지하는 경우도 있 다. ${ }^{8)}$ 증상의 정도는 유출된 외림프액의 양에 따라 다양하여, 경도의 외상에 의한 외림프누공의 경우 어지럼증과 난청이 경 미하게 나타나므로 초기에 진단이 늦어질 수 있다.") 또한 경미 한 압력 외상 등은 환자가 기억을 못하는 경우도 있고, 병력 청취 시 외상력에 대하여 자세한 문진을 시행하지 않은 경우, 특발성 감각신경성 난청으로 생각하여 압력 외상에 의한 외 림프누공을 의심하지 못하는 경우가 많다.

외림프누공의 정확한 진단은 고실개방술을 시행하여 정원 창이나 난원창에서 외림프누공을 확인하는 것이 가장 확실 한 방법이다. 조기에 고실개방술을 시행하지 않으면 외림프누 공을 진단하기 어렵고, 고실개방술을 시행한다고 하더라도 외림프의 총량은 $30 \mu \mathrm{L}$ 정도이므로 수술 중에 실제로 확인 하기 어려운 경우가 많다. ${ }^{5)}$ 저자들은 이전 연구를 통해서 병 력과 증상, 검사 소견을 통해서 외림프누공을 의심할 수 있는 진단기준을 발표하였다.,10) 확실한 압력외상의 병력이 있으면 서 외상 이후에 돌발성 난청과 비특이적인 체위성 안진을 보 이는 경우 외림프누공을 의심할 수 있다. 따라서 본 진단기준 에 따라 확실한 압력 외상 후에 외림프누공을 의심할 만한 증상과 체위성 안진 소견이 확인되어 외림프누공이 의심이 되는 경우에는 조기에 수술적 치료를 하여 청력과 어지럼의 개선을 가져올 수 있었다. ${ }^{8}$

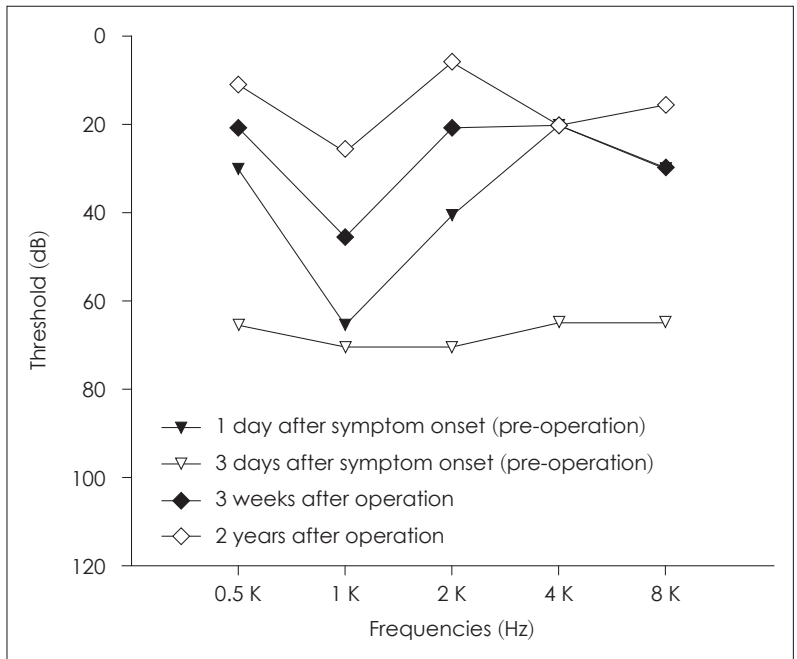

Fig. 1. Hearing changes over time (case 1).
저자들은 분만 이후 수유 중 갑자기 발생한 난청을 주소로 내원한 환자에서 압력 외상의 뚜렷한 병력을 가지고 있지 않 았지만 진행성 난청과 체위성 안진의 소견을 보여 외림프누 공을 의심하여 수술을 시행한 2예를 경험하였다. 수술 직후 증상의 호전을 보여 자발성(특발성) 외림프누공의 가능성과 함께 출산 및 수유에 의한 호르몬의 변화가 외림프누공을 일 으킬 수 있는 가능성을 높일 수 있는지를 문헌 고찰과 함께 보고하고자 한다.

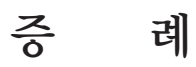

\section{증례 1}

기저질환이 없는 37세 여자 환자가 출산 후 수유 중 발생한 우측 귀의 난청과 이충만감을 주소로 외래에 내원하였다. 상 기 환자는 증상 발생 다음날 개인 이비인후과에 내원하여 돌 발성 난청 의심하 고용량 스테로이드를 처방 받아 3 일간 복 용하였으나 난청과 이충만감이 점점 악화되는 양상을 보여 증상 발생 3 일째에 본원 외래에 내원하였다. 증상 발생 시 힘 을 주거나 두부 외상의 병력은 없었고 모유 수유를 하던 것 이외에는 특이사항이 없었다.

환자는 증상 발생 다음날 타원에서 시행한 순음청력검사 는 6 분법상 $45 \mathrm{~dB}$ 이었으나 증상 발생 3 일 후에는 $82.5 \mathrm{~dB}$, 어음분별력은 $18 \%$ 로 악화되었다(Fig. 1). 내원 당시 주관적인 어지럼은 없었으나 체위성 안진검사를 시행했을 때 양측 head roll 검사나 Dix-Hallpike 검사에서 모두 1분 이상 지속되는 하향성 안진을 관찰할 수 있었으며, Dix-Hallpike 검사에서 앉을 때 안진의 방향이 상향성으로 바뀌었다(Table 1). 상기 환자는 뚜렷한 외상력은 없었으나 갑자기 발생한 진행성 난청 및 이충만감과 함께 체위성 안진검사상 체위 방향에 관계없 이 작은 진폭의 하향성 안진이 피로도 없이 관찰된다는 점에 서 외림프누공 가능성이 있다고 판단하여 증상 발생 4 일째 되던 날, 시험적 고실개방술을 시행하였다.

고실개방술을 시행하면서 내시경으로 중이강을 관찰 시 뚜렷한 외림프액 유출 소견은 관찰되지 않았으나 정원창과 난원창 주변을 연부조직과 연골, 섬유소 접착제를 이용하여 보강 후 수술을 종료하였다.

수술 3주 후 시행한 순음청력검사상 우측 청력이 $28 \mathrm{~dB}$ 로 회복되었으며(Fig. 1), 체위성 안진검사상에서 안진은 소실되었

Table 1. Videonystagmography results on 3 days after symptoms onset (case 1)

\begin{tabular}{cccc}
\hline Time & Dix-Hallpike test & Head roll test & Characteristic \\
\hline Day 3 & Rt: down beating & Rt: down beating & Fatigability $(-)$ \\
& When sitting, nystagmus direction changed to upbeating & Lt: down beating & Low amplitude \\
& & & Duration $>1$ min \\
\hline
\end{tabular}


다. 수술 후 2 년째 시행한 순음청력검사상 우측 청력 $16.6 \mathrm{~dB}$ 로 확인되었으며 어지럼 등 증상이 없어 추적 관찰을 종료하였다.

\section{증례 2}

28세 여자 환자가 5일 전 특별한 외상 없이 발생한 어지럼 및 좌측 난청을 주소로 본원 외래 내원하였다. 상기 환자는 3 주 전 출산을 하였고, 모유 수유를 하는 중이었다. 갑자기 좌측 이충만감이 발생하였고, 증상 발생 3시간 후 체위 변화 에 따른 어지럼이 발생하였다. 시간이 지날수록 난청이 점차 심해져, 환자는 개인 이비인후과에 내원하여 고실 내 스테로 이드 주입술을 총 3 회 시행받았다. 그러나 스테로이드 주입술

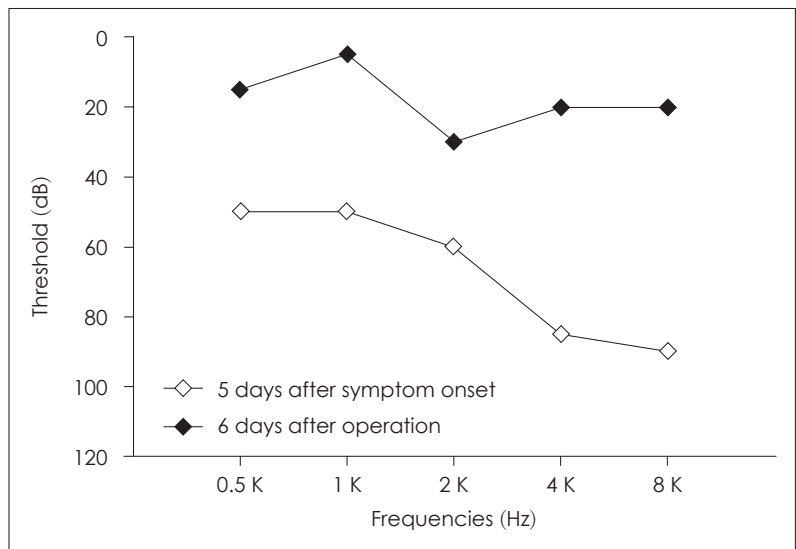

Fig. 2. Hearing changes over time (case 2).
시행 후에도 청력저하가 점차 악화되었고 어지럼 또한 심해 져 본원 외래에 내원하였다. 내원일에 시행한 순음청력검사상 환자의 좌측 청력은 6분법상 $60 \mathrm{~dB}$ 로 확인되었다(Fig. 2). 자 발안진은 뚜렷하지 않았으며, 체위성 안진검사상 안진은 관찰 되지 않았으나 체위 변환 시 심한 어지럼을 호소하였다. 이에 어지럼 평가를 위해 전정기능 검사를 시행하였다. 증상 발생 5 일째 시행한 온도안진검사상 반고리관 마비 소견은 관찰되 지 않았다(Fig. 3). 이외에도 비디오 두부충동검사 등 추가적 인 전정기능검사를 시행하고자 하였으나, 환자의 어지럼이 심 하여 검사를 시행하지 못했다.

특정 방향성 없이 체위 변화에 따른 어지럼증이 심화된다는 점에서 일반적인 양성 발작성 두위변환 어지럼(benign paroxysmal positional vertigo, BPPV)과는 다르다고 생각하였고, 시간이 지날수록 악화되는 어지럼이 있으나 온도안진검사상 반고리관 마비 소견은 보이지 않으며 체위성 안진검사에서도 뚜렷한 안진의 방향성이 보이지 않는다는 점에서 내이염이나 돌발성 난청과 동반된 현훈과는 양상이 다르다고 판단하였 다. 환자의 외상력이 명확하지는 않았으나 돌발성 난청이 진 행되고 시간 차이를 두고 어지럼이 발생하였고, 시간이 지날 수록 어지럼이 악화된다는 점을 고려했을 때 외림프누공의 가능성이 있다고 판단하여 국소마취하 시험적 고실개방술을 시행하였다.

수술 시 중이강 내 정원창 및 난원창 주변에 수양성 액체나

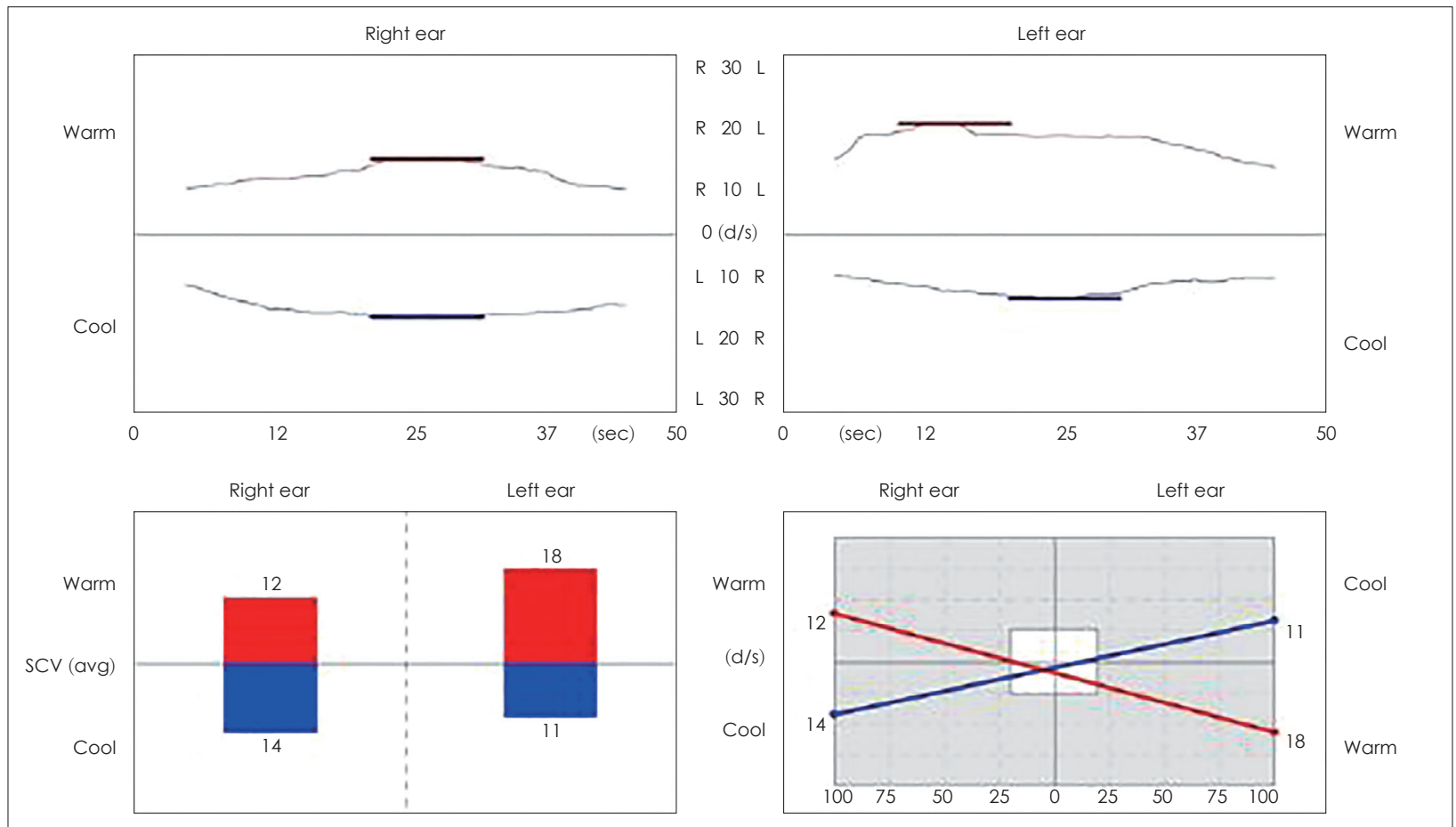

Fig. 3. The result of caloric test (case 2). SCV: slow component velocity, avg: average. 

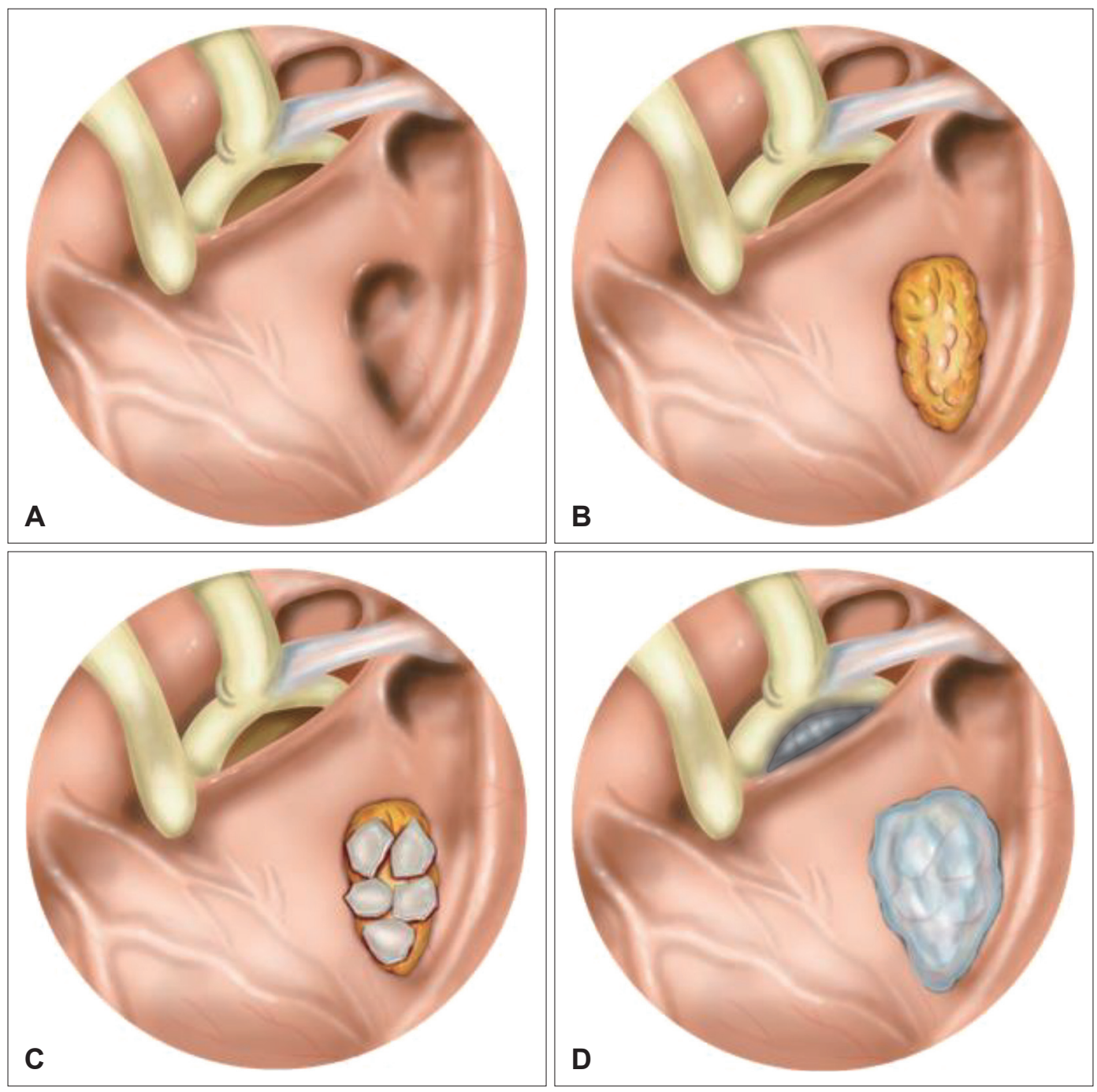

Fig. 4. Investigation of RW and OW (A). Evaluation the leakage of perilymph or fibrous web formation around RW or OW. Soft tissue (B) and cartilage $(C)$ was covered over the RW. Fibrin glue was applied over the cartilage (D). RW: round window, OW: oval window.

Table 2. Characteristics of positional nystagmus over time (case 2)

\begin{tabular}{llll}
\hline \multicolumn{1}{c}{ Time } & \multicolumn{2}{c}{ Dix-Hallpike test } & \multicolumn{1}{c}{ Head roll test } \\
\hline Preoperative & Rt: negative & Rt: negative & Subjective dizziness, regardless of position \\
& Lt: negative & Lt: negative & \\
Postoperative day 27 & Rt: upbeating & Rt: upbeating & In test, subjective dizziness is significantly reduced \\
& Lt: upbeating & Lt: upbeating, horizontal geotrophic & \\
\hline
\end{tabular}

누공은 관찰되지 않았으나 연부조직과 연골, 섬유소 접착제 를 이용해 정원창과 난원창을 보강하고(Fig. 4) 수술을 종료 하였다.

수술 6일 후, 어지럼 및 주관적인 청력저하는 호전된 상태 였으나 이명이 남아있었고, 순음청력검사상 좌측 청력은 20 $\mathrm{dB}$ 로 확인되었다(Fig. 2). 수술 1개월째 체위성 안진검사를 시행했을 때, Dix-Hallpike 및 head roll 검사에서 모두 상 향성 안진이 관찰되었으나 환자가 호소하는 어지럼은 없었으
며(Table 2), 청력 또한 정상으로 회복되었다.

\section{고 찰}

본 증례의 두 환자는 갑자기 발생한 일측 청력저하를 주소 로 외래에 내원하였다. 두 환자의 공통점은 출산 후 모유 수 유 중인 상태였으며, 특별한 압력 외상의 병력은 없었으나, 일측의 돌발성 난청이 발생되었고 시간에 따라 청력저하가 
진행하는 양상을 보였다. 또한 체위성 안진검사에서 비특이 적 안진이 발생하거나 주관적 어지럼을 호소하였으며, 시간이 지날수록 어지럼이 악화되는 양상을 보였다. 이에 외림프누 공 의심하 고실개방술을 시행하였고, 수술 소견상 누공의 존 재를 명확히 확인할 수는 없었지만, 난원창과 정원창 부분을 연부조직과 연골, 섬유소 접착제를 이용하여 보강하였고, 환 자는 수술 후 청력 및 어지럼의 개선을 보였다.

외림프누공을 진단하는 명확한 기준 및 검사법은 없다.10) 따라서 병력과 신체진찰 소견을 종합하여 외림프누공을 의 심하는 것이 중요하다. 그러나 외림프누공은 빈도가 높은 질 환이 아니기 때문에 진단에 앞서 다른 질환의 가능성을 염두 하고 배제진단을 시행하는 것이 중요하다. 외림프누공은 청 력저하와 체위성 현훈을 동반하는 것이 일반적이므로 돌발성 난청에 동반된 현훈 및 메니에르병의 초기 증상이 유사하게 나타날 수 있다. 그러나 돌발성 난청에 동반된 현훈 및 메니 에르병에 의한 어지럼은 지속 시간이 48시간 이상 지속되는 경우는 드문 반면, ${ }^{11,12)}$ 외림프누공의 현훈은 누공을 통하여 외림프액 유출이 지속되면 증상이 호전되지 않고, 시간이 지 날수록 어지럼이 악화되는 경향이 있다. 수술 전 배제 진단을 위하여 전정기능검사를 시행해 볼 수 있으나, 메니에르병의 초기나 돌발성 난청에 동반된 현훈에서도 전정기능이 정상으 로 나오는 경우가 있어, ${ }^{11}$ 전정기능검사만으로 질환을 구분하 는 것은 쉽지 않다. 그러나 외림프누공이 빈도가 높지 않은 질환인만큼 전정기능검사, 누공검사, 측두골 전산화단층촬영 을 포함해 수술 전 충분한 검사를 통하여 배제진단을 시행 하는 것은 중요하다.

최근에 저자들은 외림프누공을 의심할 수 있는 병력과 진 찰소견으로 통해서 진단기준을 발표한 바가 있다. ${ }^{10)}$ 대부분의 압력외상성 외림프누공의 경우, 외상이 난청 또는 어지럼 전 에 선행되기 때문에 내이에 압력변화를 일으킬 만한 외상의 병력, 예를 들어 코를 세게 풀거나 힘주는 행동 등이 선행되었 는지 확인해야 한다. 그러나 드물게 선행된 압력외상이 뚜렷 하지 않을 수 있고, 환자들이 외상력을 정확히 기억하기 어렵 기 때문에 진단에 어려움을 겪을 수 있다.5) 본 증례의 환자 들은 또한 본인이 기억하는 특별한 외상의 병력을 가지고 있 지는 않았다. 그러나 출산 후 계속 피곤한 상태를 유지하고, 신생아를 돌보는 과정 중에 가벼운 압력 외상이 있었을 가능 성은 있다.

특별한 외상의 병력없이 발생하는 자발적(특발성) 외림프 누공은 Stroud 등에에 의해 보고되었으나 여전히 논란이 많 은 상태이다. Shea)는 자발적 외림프누공은 있을 수 없다고 단언하였지만, 특발성 외림프누공의 가능성을 주장하는 사 람들은 일상 생활에서 일어나는 웃음이나 머리를 숙이는 등
가벼운 동작도 외림프누공을 일으킬 수 있다고 보고하였다. 이러한 쉽게 잊을 수 있는 일상 생활에 가까운 가벼운 압력 외상에 의해서 외림프누공이 발생된다는 것은 아마도 외림프 누공을 일으킬 수 있는 해부학적 소질이 개인에게 있을 것으 로 생각하고 있다. ${ }^{6,13-15)}$ Kohut 등 ${ }^{15)}$ 은 fissula ante fenestru에 내이와 연결된 누공이 있다고 확인하였고, Wackym 등은 내이의 otic capsule dehiscence syndrome이 외림프누공의 증상과 유사한 증상을 일으킬 수 있다고 하였다. 이러한 골 결손이 존재하는 경우에 누구나 일상 경험할 수 있는 가벼운 외상으로도 외림프누공의 증상을 보일 수 있을 것이다. 이는 영상학적으로 확인하기 어려운 구조의 변화이므로 외림프누 공의 의심은 환자가 느끼는 증상과 진찰 소견으로 확인하여 야 한다.

본 증례의 경우는 두 환자 모두 모유 수유를 시행하던 기 간에 외림프누공이 발생했다는 공통점이 있다. 임신 혹은 출 산이 내이 환경에 미치는 영향에 대한 선행 연구는 많지 않으 나, 에스트로겐이 내이를 보호하는 효과가 있다는 연구들은 있다. ${ }^{16,17)}$ 폐경기의 에스트로겐 저하는 섬유세포와 콜라겐의 변화를 가져와서 정원창이나 난원창의 구조 및 움직임에 영 향을 준다는 선행 연구는 있으나, ${ }^{18)}$ 이러한 변화와 외림프누 공의 연관성에 대하여 아직 알려진 바는 없다. 또한 수유부 의 프로락틴 분비에 의한 에스트로겐 저하가 내이 환경 변화 에 폐경기 여성과 같은 효과를 주는지에 대한 연구가 시행된 바가 없어, 수유부의 호르몬 변화와 외림프누공 간 연관성에 대하여는 추가적인 연구가 필요하다.

외림프누공에서 나타나는 난청은 시간에 따라서 진행한다 는 것이 특징적이다. 일반적으로 외림프누공이 발생되어 외림 프의 누출이 시작된다면, 압력외상을 받은 후 초기에는 이명 이나 먹먹한 증상이 시작되다가 시간이 지나면서 난청이 심 해짐을 느끼게 된다. ${ }^{9}$ 스테로이드에 반응하지 않은 진행성 난 청이 수술 후에 바로 좋아지는 현상은 외림프누공의 가능성 을 높여준다. ${ }^{19)}$ 또한 외림프누공을 의심할 수 있는 가장 특징 적인 증상은 어지럼과 관련된 특징적인 체위성 안진이다. 일 반적으로 외림프누공의 환자에서 가장 흔한 증상은 어지럼 이다. ${ }^{720)}$ 어지럼의 양상은 대개 자세 불안 및 체위성 어지럼을 호소한다. 강한 외상이 아니면 일반적으로 일측성 전정기능 의 소실이 오지 않는다. 외림프누공에서 나타나는 체위성 안 진은 전형적인 $\mathrm{BPPV}$ 의 안진과는 달리 여러 개의 반고리관이 나 이석기관이 영향을 받는 것과 같은 여러 방향의 안진이 발 생하며, 이석치환술이 도움되지 않는다. 어지럼은 오랜 시간 지속되는 경우가 흔하고, 수술로 인해 정원창이나 난원창을 보강한 후에는 호전이 된다. ${ }^{6,820)}$ 이러한 체위성 어지럼이 나 오는 기전으로는 동물 실험을 통해서 내림프관의 collapse로 
발생한다고 알려져 있고, 또한 3rd window effect를 통한 어 지럼으로 설명하기도 한다. ${ }^{12,19)}$ 외림프누공 환자들의 경우, 난 청 및 어지럼이 동시에 나타나는 경우도 있고 난청 또는 어지 럼 중 한가지만 나타나는 경우도 있어서 상기 증상을 보이는 환자들에게 자세한 병력청취를 시행해야 한다.

두 환자 모두 수술 소견상 확실한 외림프누공의 소견은 확 인할 수 없었다. 저자의 경험상 외림프누공이 의심되어서 수 술을 시행하였을 때 외림프누공의 소견이 확실히 보인 경우 와 보이지 않는 경우가 모두 있었고, 양 그룹 간에 임상적 증 상의 차이와 수술 결과의 차이는 보이지 않았다. ${ }^{8)}$ 이는 내림 프의 양이 $30 \mathrm{uL}$ 정도의 매우 적은 양이고 수술 시 마취제나 혈액으로 인해 확실히 보기 어렵기 때문에 확실한 증거를 찾 기가 어려울 수밖에 없다. ${ }^{5)}$ Cochlin-tomoprotein과 같은 외 림프액에 특징적인 단백을 검출하는 방법을 사용한다면 외 림프누공을 확실히 진단할 수 있겠지만, ${ }^{19,21)}$ 아직 상용화 되 어 있지 못하고, 결과를 얻는 데 시간이 걸리므로 수술 전에 사용하기에는 어려운 점이 있다.

시험적 고실개방술을 통한 난원창과 정원창을 연부조직이 나 연골로 막는 수술기법은 국소마취하에 어렵지 않게 시행 할 수 있고, 합병증이 거의 없으므로, 외림프누공이 의심된다 면 조기에 시행하는 것이 권장된다. 만약 실제로 외림프누공 이 지속되는 경우에 이를 막지 않는다면 청력이 호전될 가능 성은 없을 것이고, 어지럼도 계속 지속될 것이다. 선행 연구에 따르면,9) 외상 발생 이후 10 일 이내에 외림프누공 폐쇄술을 시행했던 환자들은 $50 \%$ 이상에서 수술 후 사회적응청력 수 준의 청력을 회복한 것으로 확인되었다. 그러나 어지럼은 수 술 시기와 관계없이 호전되었다. 따라서 청력의 회복을 위해 서는 충분한 배제진단을 통해 외림프누공의 가능성이 높다고 판단되는 경우에는 조기에 수술을 시행하는 것이 필요하다.

본 증례 보고를 하는 데 있어서 한계점이 존재한다. 2 개의 증례 모두 수술 시 확실한 외림프누공을 확인한 상태가 아니 므로, 확실한 외림프누공이라고 보기는 어렵다. 따라서 청력 의 개선이 스테로이드의 효과인지 수술의 효과인지 정확히 구분하기는 어렵다. 하지만 두 환자 모두에서 공통적인 것은 난청이 내과적 치료에도 불구하고, 시간에 따라서 진행한다 는 점과 어지럼 양상이 일측성 전정소실의 형태보다는 체위성 어지럼의 양상을 보이고, 전형적인 BPPV와는 다른 양상의 체위성 안진을 보인다는 점이다. 또한 주산기 여성이 신생아 를 돌보는 경우에는 여성이 모르는 압력외상이 가해질 수도 있으리라 생각된다.

따라서 단순히 어지럼을 동반한 돌발성 난청만 있는 경우 에 수술을 시행하는 것은 과잉 치료일 수 있다는 점을 명심 해야 하고, 시간이 지날수록 난청이 악화되고, 심한 체위성
안진 또는 어지럼이 동반하는 경우에는 외림프누공을 의심해 볼 수 있다. 외림프누공이 의심되는 경우 청력의 호전을 위해 서는 조기 수술적 치료가 중요하므로 특히 철저한 의심이 필 요하다.

본 증례를 통하여 뚜렷한 압력외상을 의심할만한 병력이 뚜렷하지 않다고 하더라도 진행성의 돌발성 청력소실과 함께 체위성 안진과 어지럼증이 동반되며, 스테로이드 치료에도 진 행성 청력저하가 지속된다면 외림프누공을 의심하여 조기에 시험적 고실개방술을 시행하는 것을 권장한다.

\section{Acknowledgments}

None.

\section{Author Contribution}

Conceptualization: all authors. Data curation: Minhae Park, HJ Kim. Formal analysis: Minhae Park, Won-Ho Chung. Funding acquisition: Won-Ho Chung. Investigation: Minhae Park. Methodology: Won-Ho Chung. Supervision: Won-Ho Chung. Validation: WonHo Chung. Visualization: Minhae Park. Writing_original draft: Minhae Park. Writing — review \& editing: Won-Ho Chung.

\section{ORCIDs}

Won-Ho Chung

Minhae Park

https://orcid.org/0000-0002-8483-4429

https://orcid.org/0000-0002-0836-8913

\section{REFERENCES}

1) Glasscock ME 3rd, McKennan KX, Levine SC. Persistent traumatic perilymph fistulas. Laryngoscope 1987;97(7 Pt 1):860-4.

2) Love JT Jr, Waguespack RW. Perilymphatic fistulas. Laryngoscope 1981;91(7):1118-28.

3) Stroud MH, Calcaterra TC. Spontaneous perilymph fistulas. Laryngoscope 1970;80(3):479-87.

4) Shea JJ. The myth of spontaneous perilymph fistula. Otolaryngol Head Neck Surg 1992;107(5):613-6.

5) Fitzgerald DC. Myth of spontaneous perilymph fistula. Otolaryngol Head Neck Surg 1993;109(5):967.

6) Wackym PA, Wood SJ, Siker DA, Carter DM. Otic capsule dehiscence syndrome: Superior semicircular canal dehiscence syndrome with no radiographically visible dehiscence. Ear Nose Throat J 2015; 94(8):E8-24.

7) Hornibrook J. Perilymph fistula: Fifty years of controversy. ISRN Otolaryngol 2012;2012:281248.

8) Ahn J, Son SE, Choi JE, Cho YS, Chung WH. Surgical outcomes on hearing and vestibular symptoms in barotraumatic perilymphatic fistula. Otol Neurotol 2019;40(4):e356-63.

9) Park GY, Byun H, Moon IJ, Hong SH, Cho YS, Chung WH. Effects of early surgical exploration in suspected barotraumatic perilymph fistulas. Clin Exp Otorhinolaryngol 2012;5(2):74-80.

10) Choi JE, Moon IJ, Kim H, Lee K, Cho YS, Chung WH. Diagnostic criteria of barotraumatic perilymph fistula based on clinical manifestations. Acta Otolaryngol 2017;137(1):16-22.

11) Pogson JM, Taylor RL, Young AS, McGarvie LA, Flanagan S, Halmagyi GM, et al. Vertigo with sudden hearing loss: Audiovestibular characteristics. J Neurol 2016;263(10):2086-96.

12) Lopez-Escamez JA, Carey J, Chung WH, Goebel JA, Magnusson $\mathrm{M}$, Mandalà $\mathrm{M}$, et al. Diagnostic criteria for Menière's disease. J Vestib Res 2015;25(1):1-7.

13) Cole GG. Validity of spontaneous perilymphatic fistula. Am J Otol 
1995;16(6):815-9.

14) Ho ML, Moonis G, Halpin CF, Curtin HD. Spectrum of third window abnormalities: Semicircular canal dehiscence and beyond. AJNR Am J Neuroradiol 2017;38(1):2-9.

15) Kohut RI, Hinojosa R, Budetti JA. Perilymphatic fistula: A histopathologic study. Ann Otol Rhinol Laryngol 1986;95(5 Pt 1):466-71.

16) Hederstierna C, Hultcrantz M, Collins A, Rosenhall U. The menopause triggers hearing decline in healthy women. Hear Res 2010;259(1-2):31-5.

17) Caruso S, Cianci A, Grasso D, Agnello C, Galvani F, Maiolino L, et al. Auditory brainstem response in postmenopausal women treated with hormone replacement therapy: A pilot study.
Menopause 2000;7(3):178-83.

18) Leblanc DR, Schneider M, Angele P, Vollmer G, Docheva D. The effect of estrogen on tendon and ligament metabolism and function. J Steroid Biochem Mol Biol 2017;172:106-16.

19) Komori M, Yamamoto Y, Yaguchi Y, Ikezono T, Kojima H. Cochlintomoprotein test and hearing outcomes in surgically treated true idiopathic perilymph fistula. Acta Otolaryngol 2016;136(9):901-4.

20) Hornibrook J. A balance test for chronic perilymph fistula. Int J Otolaryngol 2012;2012:163691.

21) Ikezono T, Shindo S, Sekiguchi S, Morizane T, Pawankar R, Watanabe A, et al. The performance of Cochlin-tomoprotein detection test in the diagnosis of perilymphatic fistula. Audiol Neurootol 2010;15(3):168-74. 